\title{
Epidemiological and Anatomopathological Characteristics of Breast Tumors in Young Women in Cotonou in the Republic of Benin from 2015 to 2019
}

\author{
Dangbemey Djima Patrice ${ }^{1,2, ~ *}$, Ogoudjobi Mathieu ${ }^{1,2}$, Aboubakar Moufalilou ${ }^{1}$, Gnangnon Freddy ${ }^{1}$, \\ Azonbakin Simon $^{1,2}$, Tognifode Veronique ${ }^{1,2}$, Lokossou Symphorose ${ }^{1}$, Hounmenou Ulysse ${ }^{1,2}$, \\ Tshabu-Aguemon Christiane ${ }^{1}$, Hounkpatin Benjamin ${ }^{1,2}$, Tonato-Bagnan Josiane ${ }^{1,2}$, \\ Denakpo Justin Lewis ${ }^{1}$
}

${ }^{1}$ Health Sciences Faculty, University of Abomey-Calavi, Cotonou, Benin

${ }^{2}$ Lagoon Mother and Child University Hospital, Cotonou, Benin

Email address:

ddpatous78@yahoo.fr (D. D. Patrice), mogoudjobi2014@gmail.com (O. Mathieu), moufaliloua@yahoo.fr (A. Moufalilou)

${ }^{*}$ Corresponding author

\section{To cite this article:}

Dangbemey Djima Patrice, Ogoudjobi Mathieu, Aboubakar Moufalilou, Gnangnon Freddy, Azonbakin Simon, Tognifode Veronique, Lokossou Symphorose, Hounmenou Ulysse, Tshabu-Aguemon Christiane, Hounkpatin Benjamin, Tonato-Bagnan Josiane, Denakpo Justin Lewis. Epidemiological and Anatomopathological Characteristics of Breast Tumors in Young Women in Cotonou in the Republic of Benin from 2015 to 2019. Journal of Gynecology and Obstetrics. Vol. 9, No. 4, 2021, pp. 104-111. doi: 10.11648/j.jgo.20210904.12

Received: June 26, 2021; Accepted: July 12, 2021; Published: July 23, 2021

\begin{abstract}
Objective: Study the epidemiological and anatomopathological characteristics of breast tumors of young woman. Patients and Methods: This was a retrospective and evaluative cross-sectional study of patients treated for a breast tumor between January 1, 2015 and December 31, 2019 in two hospitals in Cotonou. All the complete files of patients under the age of 40 treated for breast tumors of whatever nature were listed. The patients were recalled for clinical and / or radiological evaluation. The epidemiological and histological characteristics of breast tumors were analyzed. Results: The study involved 231 breast tumors including 12 cancers $(5.2 \%)$ and 219 benign tumors $(94.8 \%)$. The mean age of the patients was 25.7 years \pm 7.2. Self-examination was the most common discovery (81\%). The average consultation time was 6.4 months. The right breast and the upper-external quadrant were the most affected in 53\% and 31.1\%, respectively. Fibroadenomas (70.7\%) and invasive ductal carcinomas (9/12) were the most frequent. Obesity and a family history of breast cancer were associated with the occurrence of breast cancer in young women $(\mathrm{p} \leq 5 \%)$. The relative risk of developing breast cancer was practically zero before the age of 30. Benign breast tumors spontaneously regressed in part or in whole in $35.3 \%$ of cases ( $n=55)$, they were stable in $44.8 \%$ of cases $(n=70)$ and increased in volume in $19.8 \%$ of cases $(n=31)$. The age of diagnosis strongly influenced the evolution of tumors in the young woman in Cotonou ( $p=0.02$ ). In $56 \%$ of cases, breast tumors diagnosed before the age of 20 spontaneously resolved in part and in whole. The breast cancer case fatality in women under 40 was $11.1 \%$. Conclusion: Breast tumors in young women are mostly benign. More than half of these tumors diagnosed before the age of 20 resolve spontaneously. The risk of breast cancer is virtually zero before the age of 30 in our series.
\end{abstract}

Keywords: Tumors, Breast, Young Woman, Epidemiology

\section{Introduction}

Breast disease is very varied and affects all age groups. It is a source of anguish and discomfort. Indeed, any mastopathy, raises the fear of breast cancer. The latter is, by its frequency and severity, a real public health problem.
Breast cancer is the second deadliest cancer after cervix cancer. It is responsible for $15 \%$ of all cancer deaths. In 2018 , Africa, according to GLOBOCAN, recorded 124,179 new cases and 74,072 deaths. Benin recorded 1,526 cases of breast cancer in 2018, ranking first cancer ahead of cancer of the cervix and that of the body of the uterus talking about frequency. [1] 
Young woman's breast cancer is quite rare but very aggressive. In fact, this cancer represents 1 to $8 \%$ of all breast cancers with an incidence of 1 to 7 per 100,000 women [2]. In addition, it occurs more frequently in women who have had a family history of breast cancer and more particularly in women with a genetic mutation, in particular the BRCA gene mutation. These cancers are more aggressive and responsible for higher mortality and lower survival. In contrast to this table, benign lesions are much more frequent and young age seems to be a prime target with $90 \%$ benign masses in women aged 20 to 50 [3]. Benign lesions are mostly fibroadenomas, with a good prognosis and do not require special monitoring. However, they cause functional discomfort, and in some rare cases hide a cancerous lesion when breast surgery recommendations are not followed. This high frequency of benign tumors in this age group could explain the trend of poor surgical practice on breast tumors sometimes observed in some hospitals. This is why we have given ourselves as objective to study the epidemiological and anatomopathological characteristics of breast tumors in young women under 40 years old.

\section{Patients and Methods}

We carried out a retrospective, descriptive and analytical cross-sectional study. It took place in Cotonou in the gynecology departments of the CHU-MEL and the Menontin zone hospital between January 1, 2015 and December 31, 2019 Data collection took place between January and September 2020. Complete records of patients, aged less than 40 years, followed for breast tumors of whatever nature were included. The sampling was non-probability and consisted of identifying all files that met the criteria. The variables studied were related to descriptive and analytical epidemiological data, histological data and tumor development. A tabulation sheet containing all these characteristics was used for data collection.

The $\mathrm{Chi}^{2}$ test and Yate test made it possible to search for associations between the variables.

Statistical significance is established for a $\mathrm{p}$ value less than or equal to $5 \%$.

\section{Results}

\subsection{Epidemiological Characteristics}

\subsubsection{Frequency}

Out of 4562 registered gynecological consultations, 344 were for breast tumors in women under 40 years of age. That is to say a frequency of $7.5 \%$ of admissions.

Of 231 fully explored breast tumors in the young woman, $12(5.2 \%)$ were malignant and $219(94.8 \%)$ were benign.

\subsubsection{Sociodemographic Characteristics of the Patients}

The mean age of the patients was 25.7 years \pm 7.2 years.

The mean age at breast cancer diagnosis in our series was $33.5+/-3.5$ years.

Students were the most numerous in our study and represented $43.9 \%(n=151)$ of cases. Civil servants and other occupations (housewives, workers, shopkeepers) represented $13.7 \%(n=47)$ and $42.4 \%(n=146)$ respectively.

Regarding educational attainment, 93.3\% ( $\mathrm{n}=321)$ were educated and $88.7 \%$ had at least high school $(\mathrm{n}=301)$.

Of all patients, $51.7 \%$ were single $(n=178)$ and $46.5 \%$ $(\mathrm{n}=170)$ were common-law or married. The remainder, $1.7 \%$ $(n=6)$ were widowed or divorced women.

\subsection{Risk Factors for Breast Cancer}

\subsubsection{Physiological Factors}

The mean age of the menarche was 14.34 years. Early menarche $(<12$ years) was found in $4.5 \%$ of patients $(n=15)$ and late menarche ( $>16$ years) in $22.1 \%$ of patients $(n=73)$.

Nulliparous and first-time mothers $(n=253)$ were in the majority $(73.5 \%)$, pregnancy was late in $7.8 \%(n=27)$ of patients, $11.6 \%$ were on oral hormonal contraception among the 256 responses obtained.

Breast feeding was achieved by $88.3 \%(n=136)$ of the mothers in our series. Overweight $(25<\mathrm{BMI}<30)$ or obesity $(B M I \geq 30)$ was recorded in $44 \%(n=129)$ of patients among the 292 responses.

Table 1 shows the physiological risk factors for cancer in our study population.

Table 1. Distribution of patients according to cancer risk factors.

\begin{tabular}{|c|c|c|}
\hline Risk factors & Headcount $(n=344)$ & Percentage $(\%)$ \\
\hline \multicolumn{3}{|l|}{ Menarche (age) } \\
\hline$<12$ & 15 & 4,4 \\
\hline $12-16$ & 256 & 74,4 \\
\hline$>16$ & 344 & 21,2 \\
\hline \multicolumn{3}{|l|}{ Parity } \\
\hline Nulliparous & 186 & 54,1 \\
\hline Primipara (1) & 64 & 18,6 \\
\hline Pauciparous (2-3) & 62 & 18,0 \\
\hline Multiparous $(\geq 4)$ & 28 & 8,1 \\
\hline Unknown & 04 & 1,2 \\
\hline \multicolumn{3}{|l|}{ First pregnancy age } \\
\hline$<20$ & 21 & 6,1 \\
\hline $20-24$ & 67 & 19,5 \\
\hline $25-29$ & 39 & 11,3 \\
\hline$\geq 30$ & 27 & 7,8 \\
\hline Non pregnancy & 186 & 54,1 \\
\hline Unprecised & 04 & 1,2 \\
\hline \multicolumn{3}{|c|}{ Estro- progesterone contraception } \\
\hline Yes & 40 & 11,6 \\
\hline No & 216 & 62,8 \\
\hline No answers & 88 & 25,6 \\
\hline Breast feeding & $(n=154)$ & \\
\hline Yes & 136 & 88,3 \\
\hline No & 18 & 11,7 \\
\hline Body Mass Indes (BMI) & $(n=292)$ & \\
\hline$<18,5$ & 57 & 19,5 \\
\hline $18,5-24,9$ & 106 & 30,8 \\
\hline $24,9-29,9$ & 101 & 34,6 \\
\hline$\geq 30$ & 28 & 9,6 \\
\hline
\end{tabular}

Nulliparous $=0$ childbirth; primiparious $=1$ childbirth, pauciparous $=2$ to 3 childbirth; multiparous $\geq 4$ childbirth

\subsubsection{Comorbidities and Family History of Breast Cancer}

Co-morbidity and family history of breast cancer accounted for $24.7 \%(n=85)$. 
Co-morbidities were represented by diabetes and high blood pressure in $7.7 \%(\mathrm{n}=26)$, additions such as alcoholism and smoking in $8 \%(n=28)$ of patients.

A history of mastopathy was noted in $9 \%(n=31)$, a family history of breast cancer was found in $6.9 \%$ of patients $(n=17)$ including $2.3 \%(\mathrm{n}=8)$ in the first degree and $2.8 \%(\mathrm{n}=9)$ in the second degree.

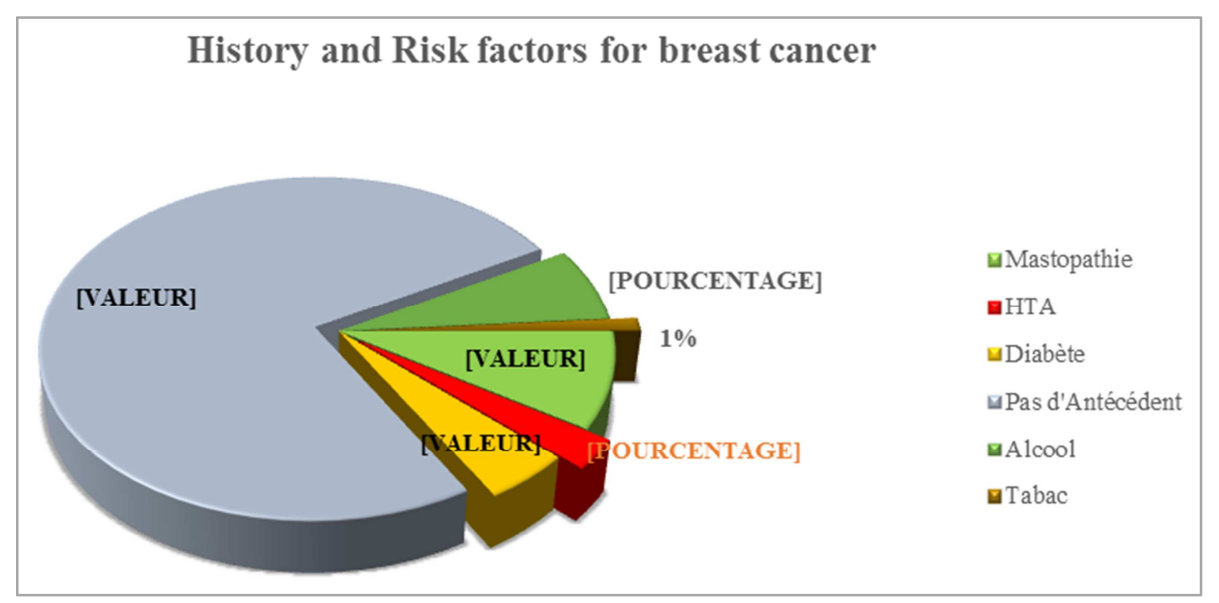

Figure 1. Shows the comorbidities and family history of breast cancer.

\subsection{Circumstances of Discovery and Reason for Consultation}

The main circumstance of discovery was self-examination. It accounted for $81 \%(n=279)$ of the circumstances of discovery. The other circumstances (19\%) were breast heaviness and routine medical examination. The discovery of a breast mass was the most frequent reason for consultation in $88 \%$ of cases $(n=303)$. The other reasons were breast discharge or tension. The mean time to consultation was 6.4 months with extremes of 06 days and 05 years.

The right breast was the most affected by the tumor in a proportion of $53.7 \%(\mathrm{n}=185)$ and the superior external quadrant was the most frequent location in $31.1 \%(n=58)$.

\subsection{Morbi Mortality from Breast Tumor in Under 40}

Local recurrence was observed in 1 in 4 cases, death from breast cancer in 1 in $9(11.1 \%)$ and in 1 in 4 patients were lost to follow-up.

\section{Factors Associated with Breast Cancer in Young Women}

\subsection{Non-modifiable Factors}

Analysis of non-modifiable factors found a statistically significant correlation between family history and the occurrence of cancer $(\mathrm{p}=0.05)$.

The risk of developing breast cancer was virtually zero for patients under the age of 30 . This risk was significant from the age of 30 .

The mean age at breast cancer in our series was $33.46 \pm 3.5$ years.

Table 2 shows the association between non-modifiable risk factors and breast cancer.
Table 2. Correlation between risk factors and the occurrence of breast cancer in young women under 40.

\begin{tabular}{|c|c|c|c|c|}
\hline & \multicolumn{2}{|c|}{ Malignant tumors } & \multirow{2}{*}{ RC [IC95\%] } & \multirow{2}{*}{ P-value } \\
\hline & Oui & Non & & \\
\hline \multicolumn{5}{|l|}{ AGE } \\
\hline $10-19$ & 0 & 1 & $0,76[0,03 ; 19,9]$ & \multirow{5}{*}{0,48} \\
\hline $20-24$ & 0 & 3 & $0,30[0,01 ; 6,3]$ & \\
\hline $25-29$ & 2 & 9 & $0,44[0,08 ; 2,4]$ & \\
\hline $30-35$ & 5 & 9 & $1,5[0,39 ; 6,3]$ & \\
\hline $35-39$ & 5 & 7 & $2,24[0,53 ; 9,3]$ & \\
\hline \multicolumn{5}{|c|}{ Menarche (age) } \\
\hline$<12$ & 0 & 2 & 1 & \multirow{3}{*}{0,59} \\
\hline $12-16$ & 9 & 19 & $1,57[0,34 ; 7,17]$ & \\
\hline$>16$ & 3 & 9 & $0,74[0,16 ; 9,36]$ & \\
\hline \multicolumn{5}{|c|}{ Mastopathy } \\
\hline Yes & 0 & 3 & $0,30[0,01 ; 6,32]$ & \multirow{2}{*}{0,24} \\
\hline No & 12 & 26 & 1 & \\
\hline \multicolumn{5}{|l|}{ Diabetes } \\
\hline Yes & 0 & 2 & $0,44[0,02 ; 9,85]$ & \multirow{2}{*}{0,35} \\
\hline No & 12 & 27 & 1 & \\
\hline \multicolumn{5}{|c|}{ High Blood Pressure } \\
\hline Yes & 2 & 3 & $1,73[0,25 ; 11,9]$ & \multirow{2}{*}{0,57} \\
\hline No & 10 & 26 & 1 & \\
\hline \multicolumn{5}{|c|}{ Family History of cancers } \\
\hline Yes & 1 & 11 & $0,14[0,02 ; 1,3]$ & \multirow{2}{*}{0,05} \\
\hline No & 11 & 18 & 1 & \\
\hline
\end{tabular}

\subsection{Modifiable Factors}

The body mass index was the only modifiable factor associated with the occurrence of cancer in our series with a relative risk equal to 14 for BMIs greater than $30 \mathrm{~kg} / \mathrm{m}^{2}$ $(\mathrm{p}=0.02)$.

Evolution of breast tumors according to the age of the patients.

Of 344 tumors followed, 156 were favorable for evaluation. Of this number, $35.3 \%(\mathrm{n}=55)$ spontaneously regressed in part or in whole, $44.8 \%(n=70)$ were stable and $19.8 \%(n=31)$ increased their volume.

Age at diagnosis strongly influenced the evolution of 
tumors in the young woman in Cotonou ( $\mathrm{p}=0.02)$.

More than half $(56 \%)$ of breast tumors diagnosed before the age of 20 spontaneously resolved in part and in whole.

Table 3 shows the evolution of breast tumors as a function of age at diagnosis.

Patients operated on for benign tumors no longer presented any mass in $80 \%$ of cases. A new mass had been found in $20 \%$ of them.

Table 3. Evolution of breast tumors according to age at diagnosis.

\begin{tabular}{lllll}
\hline Age & $<\mathbf{2 0}$ & $\mathbf{2 0}$ à $\mathbf{3 0}$ & $\mathbf{> 3 0}$ & Total \\
\hline Total regression & $11(47,8 \%)$ & $6(26,1 \%)$ & $6(26,1 \%)$ & 23 \\
Partial regression & $16(50 \%)$ & $9(28,1 \%)$ & $7(21,9 \%)$ & 32 \\
Stability & $13(18,5 \%)$ & $33(47,1 \%)$ & $24(34,3 \%)$ & 70 \\
Increase & $8(25,8 \%)$ & $13(41,9 \%)$ & $10(32,3 \%)$ & 31 \\
Total & 48 & 61 & 47 & 156 \\
\hline
\end{tabular}

\section{Anatomopathological Characteristics}

\subsection{Nature of the Tumor}

Clinical examination and imaging had made it possible to suspect 184 adenofibromas (83.9\%), 26 mammary cysts (11.9\%), 5 intramammary lymph nodes $(2.3 \%), 02$ low-grade phyllodes tumors $(0.9 \%), 01$ lipoma $(0.5 \%), 01$ papilloma without atypia $(0.5 \%)$.

Out of 56 breast biopsies prescribed for breast tumors classified at least ACR4 and / or presented with clinicoradiological discordance, 41 actually performed the pathological examination with the results of $29(70.7 \%)$ benign tumors and $12(29,3)$ malignant tumors. (Table 4)

Table 4. Histological type of tumors.

\begin{tabular}{llll}
\hline Nature of the tumor & Hystological types & Headcount (n) \\
\hline & Adénofibroma (FA) & 19 \\
& fibrocystic dystrophy & 6 \\
Benign & low grade phyllid papilloma tumor & 2 & 70,7 \\
& Lipoma & 1 & 19,6 \\
& Papilloma & 4,9 \\
& Total & 2,4 & 29 \\
& invasive ductal carcinoma & 9 & 2,4 \\
Malignant & ductal carcinoma in situ & 2 & 100 \\
& invasive lobular carcinoma & $9 / 12$ & 1 \\
& Total & $12 / 12$ \\
\hline
\end{tabular}

\subsection{Histopronostic Grade and Immunohistochemical Profile}

The histopronostic grade was moderate to high (II or III) in 9 out of 12 cases and mild (I) in 3 out of 12 cases.

The immunohistochemical profile was "triple negative" in 3 out of 12 cases, luminal A in 2 out of 12 cases, luminal B in 4 out of 12 cases and unspecified in 3 out of 12 cases.

\section{Discussion}

\subsection{Prevalence of Breast Tumors in Young Women Under 40}

Benign tumors represented $94.8 \%$ of breast tumors in our series. Several authors from the West African sub-region have reported similar prevalences. Bonané-Thiéba and al, in 2010 in Ouagadougou, reported a prevalence of benign breast tumors of $88.9 \%$ before the age of 40 [4]. Njeze in 2014 in Nigeria found a prevalence of $83 \%$ for an average age of 26 years [5]. All these data from the literature show that breast tumors in young women are generally benign. Faced with the flurry of benign breast tumors in this young population, special attention must be observed by the practitioner so as not to miss breast cancer.
Breast cancers in young women under 40 represented 5.2\% of breast tumors in our series. For Njeze and Bonane-Thieba et al, the prevalence was respectively $16.8 \%$ and $11.1 \%[4,5]$. These high rates found by these authors could be explained by the fact that the cases were directly recruited from anatomy pathology laboratories where the examination request related to suspected cases of malignancy and moreover these laboratories did not receive the majority of tumors judged benign on imaging.

\subsection{Socio-demographic Characteristics}

\subsubsection{Age}

The mean age of the patients in our study was $25.7 \pm 7.2$ years. In Senegal in 2016, Gueye et al found 25 years as the average age of benign breast tumors with $70 \%$ of patients under 30 years [6]. Patients under the age of 30 represented $84.6 \%$ of our study population. In Burkina-Faso in 2010, Bonane-Thieba et al found an average age of 24.1 years with $78.8 \%$ of cases being less than 30 years old [4]. These data support the hypothesis according to which youth is the target of breast tumors.

The mean age of the patients with malignant tumors in our series was $33.46 \pm 3.5$ years with 02 cases notified before the age of 30 years. This average age is slightly higher than that 
reported in African literature for young women. Darre et al in 2017 in Togo, Bonane-Thieba et al in 2010 in Burkina-Faso, Bouzid et al in 2013 in Tunisia, and Gueye et al in 2016 in Senegal had respectively found an average age of 32.6 years, 31,3 years, 30.9 years and 29.7 years [4-8]. The average age of cancer in young women in Cotonou is comparable to data from Western authors. Mouret et al [9] in France in 2010 and Mc Aree et al in Ireland in the same year [10] had respectively noted an average age of 35.2 years and 34.9 years.

These different data show that breast cancer occurs at much younger ages in developing countries compared to those in developed countries. A much more powerful study in Benin will confirm the difference observed with data from the African region.

\subsubsection{Occupation and Level of Education}

Almost all of the patients were educated (94.8\%), with a large proportion of male and female students. The setting chosen for this study, the metropolis of Benin, could be a bias in relation to the level of education. The education of young girls would facilitate knowledge about breast cancer and encourage consultation requests. Ifediora and Azuike [11] in Nigeria in 2018 showed that $87 \%$ of secondary school students had heard of breast cancer once and $52.9 \%$ were informed of the breast self-examination technique and the need for consultation. in the event of an anomaly. Sambanje and Mafuvadze [12] in Angola in 2012 had reached the same conclusion. According to their series, more than $70 \%$ of the students surveyed said they knew about breast cancer and breast self-exams. However, less than $40 \%$ of them were able to cite risk factors and signs of this cancer.

According to the 2017-2018 EDSB in Benin [13] more than one in 02 women is uneducated $(55 \%)$. This shows the great awareness-raising effort that remains to be provided to the population of Benin in general and that of Cotonou in particular, especially uneducated, for the regular practice of breast self-examination and medical consultation upon discovery of a breast mass.

\subsection{Risk Factors Associated with the Onset of Breast Cancer}

\subsubsection{Age}

The mean age of subjects with breast cancer in our series was $33.46 \pm 3.5$ years with $83.3 \%$ of cases aged 30 to 40 years In many studies, including that of Meviel et al in 2011, age was the most important risk factor associated with the occurrence of breast cancer $(p=0.015)$ [14]. In our study, there was no significant association between age and the onset of breast cancer in young women. This could be explained by the fact that cancer is rare in our target population $(<40$ years). The risk of developing cancer increased with age in our series. Ben Abdallah et al in Tunisia in 2009 also found a similar curve with increased incidence and risk as the age of patients increased [15].

\subsubsection{Menarche}

No case of breast cancer had experienced early menarche in our series. There was no statistically significant association between the presence of early menarche and the occurrence of cancer in our study. Bouteffal et al in Morocco in 2010 [16] made the same observation. Laamiri et al in 2015 [17] found in their series that early menarche and the age of the 1st pregnancy were associated with a high risk of cancer for women between 22 and 34 years old.

\subsubsection{Oral Hormonal Contraception}

In our study, oral hormonal contraceptives were found in $11 \%$ of patients. For Iversen et al in Norway in 2011 there was no correlation between an increased incidence of cancer and the use of hormonal contraceptives. But Méviel et al had found an association for taking contraceptives over a long period (more than 10 years). [14]. Morch et al corroborated this finding by showing that the risk of developing breast cancer increased from 1.09 with less than one year of use to 1.38 after 10 years of use $(p=0.002)$ [18].

\subsubsection{Body Mass Index}

Of the 12 patients who presented with a malignant tumor, 10 were overweight and there was a statistically significant association between the occurrence of breast cancer and BMI $(p=0.02)$. In Benin, Mensah et al found that $13.6 \%$ of patients with breast tumors were overweight [19]. It reported a statistical association between weight and the occurrence of breast tumor $(\mathrm{p}=0.046)$. Méviel et al showed through their series that BMI was a significant risk factor in women under $50(\mathrm{p}<0.02)$ [14]. Msolly et al in Tunisia reported a 1.5 -fold or even 3 -fold increase in the risk of developing breast cancer for overweight or obese young patients [20]. But for Jonhson et al this link would only exist following a gain of more than $10 \mathrm{~kg} / \mathrm{m} 2$ in young women after the age of 18 [21]. Adebamowo et al in Nigeria stated that being overweight would rather have a protective role in these women and could not be a source of cancer until after menopause [22]. This means that it is important throughout her life for a woman to ensure that she maintains a normal weight through regular physical activity and a healthy diet.

To better appreciate the impact of these factors on the young Beninese woman, it would be important that other more powerful studies can be carried out.

\subsubsection{Parity}

In our series, one (1) out of three (3) breast cancer patients was multiparous. According to data in the literature, multiparity and long periods of breastfeeding are protective factors against the occurrence of breast cancer. Parity was not a significant risk factor in the occurrence of breast cancer $(p>5 \%)$ in our series. However, in the African series, a predominance of multiparous cancer patients has been noted by certain studies, including that of Walker et al in Nigeria in 2004. They reported that multiple pregnancies and deliveries could promote the occurrence of breast cancer by activation of the breast cancer. folliculin [23]. 


\subsubsection{Family History}

A family history of breast cancer was statistically associated with the risk of developing breast cancer $(p=0.05)$. In our study, $6.9 \%$ of patients had a family history of breast cancer. Darre et al in Togo in 2017 found that $13.9 \%$ of the patients in his series who had a family history and 5 of these patients out of 7 presented a mutation in the BRCA gene [7]. Gueye et al in Senegal in 2016 found $19.4 \%$ of a family history [6].

In the past, women in developing countries like Benin were protected by late puberty, early first birth and high parity. Trends have evolved in a rapid and significant way with life behaviors such as: increasingly late first birth, often no breastfeeding, a westernized diet responsible for early breast cancer and breast cancer. increased incidence.

\subsection{Histology}

Ideally, the discovery of an abnormality should be the subject of pathological research, especially when signs of suspected malignancy are found [24].

Benign breast tumor pathology was largely dominated, in our series, by adenofibromas $(70.7 \%)$ and mammary cysts (19.6\%). The same observation was made by authors such as Gueye et al in Senegal in 2017 and Mensah et al in Benin in 2015, who found $86 \%$ and $71.4 \%$ respectively of adenofibroma [6, 19]. Like other authors [4], adenofibroma dominates the benign tumor pathology of young women under 40 years of age. Histology also allowed the detection of 02 phyllodes tumors, the characters of which are superimposed on those of adenofibromas on ultrasound. In Ivory Coast Ohoui-Acko et al in 2017, exploring 51 adenofibromas on radiology, found three (03) phyllodes tumors on histology [25]. Thus, it is not uncommon for the study of adenofibromas to lead to the discovery of a phyllode tumor.

Infiltrating ductal carcinoma was the most common histological type in our series (9 out of 12 cases). In the literature Tchin Darré in Togo in 2017 found in their series $79 \%$ of invasive ductal carcinoma (ICC), Gueye et al in Senegal in $2016[6,7]$ found $88.7 \%$ of ICC. In addition to being the most common, $\mathrm{CCI}$ is an aggressive tumor. Its aggressiveness is linked on the one hand to a high frequency of undifferentiated cancers (grade II and III) and on the other hand to a greater tumor insensitivity to hormones (absence of estrogen receptors) [24]. Guendouz in 2011 found grade II in 61\%; a grade III in 35\% [26] and Mouret $42.8 \%$ of grade II and $47.9 \%$ of grade III [9]. In addition, a large number of studies including that of Sabiani et al [27] noted a relatively low frequency of positive hormone receptors and a large number of triple negative and HER 2 tumors in groups of patients under 35 years of age $[29,30]$. According to Kumar in 2016, triple negative tumors occurring at a young age have a poor prognosis with significant limits for the choice of therapeutic indications [29]. In our study, grades II and III were found for 9 out of 12 patients and three (03) among them had a triple negative tumor.

\subsection{Morbi-mortality from Cancer}

\subsubsection{Benign Tumors}

The National College of French Gynecologists and Obstetricians (GNCOF) reports that in the absence of treatment, a benign adenofibroma or cystic tumor may develop or stabilize, regress or even disappear [33]. In our series, a regression and / or disappearance of the tumor was observed in $35.2 \%$ of cases. The disappearance was more marked in women diagnosed before the age of 20 .

According to the literature following a surgical sanction, benign tumors do not recur [31]. We noted, however, that new tumors can develop in other quadrants in the same breast or in the contralateral breast.

\subsubsection{Malignant Tumors}

Malignant breast tumors occurring in young women tend to have a poor prognosis $[32,33]$. Complications occur quite frequently and can result in the death of patients. For those who survive, there is a great risk of recurrence [34].

In our study, the death of a patient and two cases of locoregional recurrence were counted in an interval of 02 years after the surgery. For Gueye et al in Senegal [6] the result is appalling with a lethality of $35.5 \%$ and an estimated average survival of 36.7 months, in relation to the difficulties inherent in starting treatment.

In our context, it will be difficult to hope for convincing results in oncology if the availability and accessibility of anticancer products, radiotherapy and a program for the early detection of breast cancer in young women under 40 [33] are not effective.

\section{Conclusion}

The results of our study show that breast tumors in young women under 40 are mostly benign. Obesity and the family history of breast cancer are associated with the onset of cancer in young women in Cotonou. The consultation time remains relatively long after discovery of the tumor by the breast selfexamination. The age at diagnosis of breast tumors in a young woman in Cotonou strongly influences her development. More than half of breast tumors diagnosed before the age of 20 resolve spontaneously in part and in whole. The risk of breast cancer is virtually zero before the age of 30 .

\section{Recommendations}

we recommend higher potency studies on young woman breast cancer to confirm our observations and study emerging risk factors for breast cancer in this young population.

\section{Ethical Considerations}

The principles of medical confidentiality, confidentiality and patient anonymity were respected. The study was authorized by the directors of the affected hospitals. 


\section{Conflict of Interest Statement}

The authors declare that they have no competing interests.

\section{References}

[1] Bray F, Ferlay J, Soerjomataram I, Siegel R, Torre L, Jemal A. Global cancer statistics 2018: GLOBOCAN estimates of incidence and mortality worldwide for 36 cancers in 185 countries. CA Cancer J Clin. 2018; 68 (6): 394-424.

[2] Marroun I, Sené T. Le nouveau dictionnaire médical. $7^{\text {ème }}$ éd. Elsevier Masson; 2017.882p.

[3] Boyle P, Levin B. World Cancer report 2008. Lyon: International Agency for Research on Cancer-OMS; 2008. 512 p.

[4] Bonane-Thieba B, Lompo-Goumbri O, Konségré V, Sawadogo J, Lamien-Sanou A, Soudré R. Aspects épidémiologiques et histopathologiques des affections mammmaires à Ouagadougou. J. Afr. Cancer. 2010; 2: 146150. DOI: $10.1007 / \mathrm{s} 12558-010-0059-3$.

[5] Njeze G. Breast Lumps: A 21-Year Single-Center Clinical and Histological Analysis. Nigerian Journal of surgery. 2014; 20 (1): 38-41. DOI: $10.4103 / 1117-6806.127111$.

[6] Gueye M, Gueye SMK, Gueye MDN, Dia FN, Gassama O, Diallo $\mathrm{M}$ et al. Cancer du sein chez la femme de moins de 35 ans: aspects épidémiologiques, cliniques, thérapeutiques et pronostiques à l'unité de sénologie du CHU Aristide le Dantec de Dakar. Médecine et Santé Tropicales. 2016; 26 (4): $377-$ 381. DOI: $10.1684 / \mathrm{mst} .2016 .0637$.

[7] Darre T, Tchaou M, Folligan k, Amadou A, N'timon B, Sonhaye $\mathrm{L}$ et al. Breast cancer cases of female patients under 35 years of age in Togo: A series of 158 cases. Mol clin oncol. 2017; 7 (6): 1125-29. DOI: 10.3892/mco.2017.1461.

[8] Bouzid N, Lahmar R, Tebra S, Bouaina N. Cancer du sein chez la femme jeune de moins de 35 ans en Tunisie: étude rétrospective à propos de 124 cas. Gynécologie Obstétrique et Fertilité. 2013; 41 (6): 356-60. D. O. I: 10.1016/j.gyobfe.2013.05.002.

[9] Mouret-Fourme E, Stevens D, Jouanneau L, Lerebours F. Cancer du sein de la femme jeune: prise en charge et suivi à l'hôpital René-Huguenin (institut Curie/Saint-Cloud) entre 1980 et 2008. $32^{\text {ème }}$ Journées de la SFSPM. Strasbourg, 2010.

[10] McAree B, O’Donnell M, Spence A, Lioe TF, McManus D, Spence RAJ. Breast cancer in women under 40 years of age: A series of 57 cases from Northern Ireland. The Breast. 2010; 19 (2): 97-104. DOI: 10.1016/j.breast.2009.12.

[11] Ifediora CO, Azuike EC. Tackling breast cancer in developing countries: insights from the knowledge, attitudes and practices on breast cancer and its prevention among Nigerian teenagers in secondary schools. J Prev Med Hyg. 2018; 59 (4): E282E300. DOI: 10.15167/2421-4248/jpmh2018.59.4.964.

[12] Sambanje MN, Mafuvadze B. Breast cancer knowledge and awareness among university students in Angola. Pan Afr Med J. 2012; 11: 70 .

[13] Institut National de la Statistique et de l'Analyse Économique (INSAE) et ICF. Enquête Démographique et de Santé au Bénin, 2017-2018. Cotonou, Bénin et Rockville, Maryland,
USA: INSAE et ICF. 2019. 15p.

[14] Merviel P, Jouvance O, Naepels P, Fauvet R, Cabry-Goubet R, Gagneur $\mathrm{O}$ et al. Existe-t-il encore des facteurs de risque de survenue d'un cancer du sein? Gyn Obst Fert. 2011; 39 (9) 486-90. DOI: 10.106/j.gyobfe.2010.10.015.

[15] Ben Abdallah M, Zehani S, Maalej M, Hsairi M, Hechiche M, et al. Cancer du sein en Tunisie: caractéristiques épidémiologiques et tendance évolutive de l'incidence. Journal de la société tunisienne des sciences médicales. 2009; 87 (7): 417-25.

[16] Boufettal H, Noun M, Samouh N. Cancer du sein chez la femme jeune au Maroc. Cancer/Radiothérapie. 2010; 14 (8): 698-703. DOI: 10.1016/j.canrad.2010.04.007.

[17] Laamiri F, Bouayad A, Hasswane N, Ahid S, Mrabet M, Amina B. Risk factors for breast cancer of different age groupe: moroccan Data? open Journal obstetrics and gynecology. 2015; 5 (2): 79. DOI: 10.4236/ojog.2015.52011.

[18] Morch L, Skovlund C, Hannaford P, Iversen L, Fielding S, Lidegard O. Contemporary hormonal contraception and the risk of breast cancer. The new England journal of medicine. 2017; 377 (23): 2228-39. DOI: 10.1056/NEJMoa1700732.

[19] Mensah E, Savi de Tove S, Koudoukpo C, Brun L, Hodonou MA, Tanou BE et al. Aspects diagnostiques et thérapeutiques des tumeurs du sein chez les consultantes admises au CHU de Parakou (BENIN). Revue de Chirurgie d'Afrique centrale. 2015; 2 (7): 27-33.

[20] Msolly A, Gharbi O, Mahmoudi K, Limen S, Hochlef M, Ben Ahmed S. Association between body mass index and risk of breast cancer in Tunisian women. Ann Saudi Med. 2011; 31 (4): 393-397. DOI: 10.4103/0256-4947.83211.

[21] Jonhson R, Anders C, Litton J, Ruddy K, Bleyer A. Breast cancer in adolescents and young adults. Pediatrie and blood cancer. 2018; e27397: 1-9. DOI: 10.1002/pbc.27397.

[22] Adebamowo CA, Ogundiran TO, Adenipekunn AA, Oyeshegun RA, Campbell OB, Akang EU. Obesity and height in urban Nigerian women with breast cancer. Ann Epidemiol. 2003; 13 (6): 455-61. DOI: 10.1016/s104-2797(02)00426-x.

[23] Walker AR, Adam FI, Walker BF. Breast cancer in black African women: a changing situation. J R Soc Promot Health. 2004; 124 (2): 81-5. DOI: 10.1177/146642400412400212.

[24] J Chiquette, JC Hogue. La Sénologie au quotidien: les défis mammaires en pratique courante. Québec: bibliothèque et Archives nationales; 2014.

[25] OHUI-ACKO EV, KOUADIO KE, DÉDÉ S, GUI-BILE N, KABAS R, KOUIS $\mathrm{S}$ et al. Adénofibrome mammaire: corrélation entre données écho-mammographiques et anatomopathologiques, à propos de 55 cas. J Afr Imag Méd. 2017; 9 (4): 187-192.

[26] Guendouz H, Chetibi W, Abdelouahab A, Bendib A. Cancer du sein de la femme de moins de 35 ans: étude rétrospective à propos de 612 cas. Dans: Damour-Terasson C, Zelek L, Espié M. La Lettre du Senologue ${ }^{\circ}{ }^{52}$. Paris: Edimark; 2011.

[27] Sabiani L, Houvenaeghel G, Heinemann M, Reyal F, Classe $\mathrm{JM}$, Cohen $\mathrm{M}$ et al. Breast cancer in young women: Pathologic features and molecular phenotype. 2016; 29: 10916. DOI: 10.1016/j.breast.2016.07.007. 
[28] Anderson KN, Schwab RB, Martinez ME. Reproductive risk factors and breast cancer subtypes: a review of the literature. Breast Cancer Res Treat. 2014; 144 (1): 1-10. DOI: 10.1007/s10549-014-2852-7.

[29] Kumar P, Aggarwal R. An overview of triple-negative breast cancer. Arch Gynecol Obstet. 2016; 293 (2): 247-69. DOI: 10.1007/s00404-015-3859-y.

[30] Bollet MA, Sigal-Zafrani B, Mazeau, Savignoni A, de la Rochefordière A, Vincent-salomon A et al. Corrigendum to "Age remains the first prognostic factor for locoregional breast cancer recurrence in young $(<40$ years) women treated with breast conserving surgery first". Radiother Oncol. 2007; 82 (3): 272-80. DOI: 10.1016/j.radonc.2007.01.001.

[31] Spitaleri G, Toesca A, Botteri E, Bottiglieri L, Rotmensz N,
Boseli S et al. Breast phyllodes tumor: a review of littérature and a single center retrospective series analysis. Crit Rev Oncol Hematol. 2013; 88 (2): 4 27-36. DOI: 10.1016/j.critrevonc.2013.06.005.

[32] Vlastos G, Rapiti E, Bouchardy C. Place de la chirurgie dans le traitement du cancer du sein métastatique d'emblée. Rev Méd Suisse. 2007; 130 (3): 11p.

[33] Amoussou-Guenou KM, Fachinan OH, Gbénou S, Komongui D, Houndétoungan G. Place de la scintigraphie et de la radiothérapie dans les évacuations sanitaires hors du Bénin de 2006 à 2010. Médecine Nucl. 2013; 37 (10): 507-10. DOI: 10.1016/j.mednuc.2013.09.009.

[34] Maughan KL, Lutterbie MA, Ham PS. Treatment of Breast Cancer. Am Fam Physician. 2010; 81 (11): 1339-46. 